\title{
Church and State in the United States: Competing Conceptions and Historic Changes
}

Douglas Laycock

University of Texas School of Law

Follow this and additional works at: https://www.repository.law.indiana.edu/ijgls

Part of the Constitutional Law Commons, and the Religion Law Commons

\section{Recommended Citation}

Laycock, Douglas (2006) "Church and State in the United States: Competing Conceptions and Historic Changes," Indiana Journal of Global Legal Studies: Vol. 13 : Iss. 2 , Article 8.

Available at: https://www.repository.law.indiana.edu/ijgls/vol13/iss2/8

This Symposium is brought to you for free and open access by the Law School Journals at Digital Repository @ Maurer Law. It has been accepted for inclusion in Indiana Journal of Global Legal Studies by an authorized editor of Digital Repository @ Maurer Law. For more information, please contact rvaughan@indiana.edu.

\section{$\Psi$}

JEROME HALL LAW LIBRARY

INDIANA UNIVERSITY

Maurer School of Law
Bloomineton 


\title{
Church and State in the United States: Competing Conceptions and Historic Changes
}

\author{
Douglas Laycock*
}

Abstract

This article, originally written for a French audience, attempts to explain the American law of church and state from the ground up, assuming no background information. Basic legal provisions are explained. The relevant American history is periodized in three alignments of religious conflict: Protestant-Protestant, ProtestantCatholic, and religious-secular: Some frequently heard concepts are explained, distinguished, and related to each other-separation, voluntarism, equality, formal and substantive neutrality, liberty, toleration, and state action. Finally, the principal disputes over religious liberty are assessed in three broad areas-funding of religiously affiliated activities, religious speech (with and without government sponsorship), and regulation of religious practice. These disputes are reviewed in historical, political, and doctrinal terms, with brief comparisons to the substantially different French solutions to the same problems.

This article, originally written for a French audience and published in French, ${ }^{1}$ attempts to explain the American law of church and state from the ground up, assuming no background information of any kind. That turned out to be a useful exercise; explaining the underlying assumptions we generally take for granted revealed insights and connections previously overlooked. I hope English-speaking readers will also find it useful.

Except for rewriting the introduction and updating the treatment of the most recent developments, I have changed very little from the version I submitted to the French translators. I retain the comparisons of what I know in depth on the American side to what I think I understand superficially on the French side. I am pleased to report that my cautious observations on French law in this

*Alice McKean Young Regents Chair, The University of Texas School of Law. J.D. 1973, University of Chicago; B.A. 1970, Michigan State University.

1. Douglas Laycock, La religion et l'État aux États-Unis: affrontement des théories et changements historiques, in LA CONCEPTION AMÉRICAINE DE LA LAÏCITÉ 35 (Elisabeth Zoller ed., 2005). I know what I said in English; I have to take the French translation as a matter of faith. 
article passed through the hands of French editors without provoking argument or corrections. But no reader should make the mistake of thinking me an expert on the French system.

It is revealing to compare how two modern democratic societies, each proclaiming its commitment to liberty and equality, have come to fundamentally different resolutions of these issues on nearly every point. France and the United States share a commitment to religious liberty. But different histories and different distributions of religious opinion have led to different understandings of what religious liberty means in practice.

The one-word label for the French system is laïcité; American scholars were invited to Paris to explain the American conception of laïcité. But I am not sure there is a relevant American conception of laïcité. To fully understand laïcité, I suspect that one must be immersed in French law and French social and political practice. In French-English dictionaries, laïcité is often omitted; when it appears, it is commonly translated as "secularism." This is probably a simplification, but let us accept it as a starting point. Many Americans would say that the United States has a secular government, or that it aspires to have a secular government. A minority of Americans would like to see a wholly secular society. But no one in the United States would use a word like "secularism" to summarize the American understanding of church-state relations.

There is no widely accepted single word to summarize the American system. Several such words have been suggested, but none of them is universally accepted. Probably the nearest equivalent in American usage is "separation of church and state," often shortened to "separation." This is a troublesome phrase even before translation; Americans dispute its meaning, and even dispute whether it describes one of our governing principles. But separation of church and state is probably the most common phrase for summarizing American church-state relations; again, let us accept it as a starting point.

Separation of church and state requires that government be separated from religion, and thus that government itself be secular. Separation means that government is not to sponsor religion, and also, although this point gets less emphasis in the rhetoric of separation, government is not to interfere with religion. Many religious believers support separation in part because they believe that religion will flourish best without government sponsorship, and that all sponsorship is a form of interference. So separation need not lead to secularism in civil society. To the contrary, many Americans believe that separation is one important reason why religious faith persists in the United States to a far greater extent 
than in most other industrialized democracies. Separation does not imply that religion is best kept out of public view, or even that private religious expression should be kept out of government institutions. I do not know the French system well enough to be sure, but I think that any correspondence between separation and laïcité is very inexact.

Other attempts to summarize the American system are that religion must be voluntary, and that government must be neutral as between religions and as between religion and religious disbelief. Each of these principles has applications that are highly controversial in the United States. Americans dispute the meaning of neutrality just as they dispute the meaning of separation. And of course, all such explanations are mere paraphrases of the operative language of the numerous constitutional and statutory provisions protecting religious liberty.

There may be no simple explanations of our system to citizens familiar with the French system, and no clearly equivalent words or phrases in our two languages for the central concepts. My only course is to explain the American system as simply and clearly as I can, with emphasis on answers to specific practical questions. I will necessarily have to generalize in places and omit important variations.

Keep in mind that on many important issues of religious liberty, there are at least two sides in the United States, with intense and sustained political and legal conflict. Our adversarial legal system, and our active system of judicial review of the constitutional validity of government practices, often enable the opposing sides in political and even religious arguments to translate their claims into legal arguments. At different times in American history, very different understandings of religious liberty have prevailed. The American conception of churchstate relations is disputed, and it changes over time.

\section{The Basic Legal Provisions}

The United States has many constitutional and statutory guarantees of religious liberty. Most important are two sentences in the Constitution of the United States. The first is the Test Oath Clause, in Article VI, clause 3, which provides: "[N]o religious Test shall ever be required as a Qualification to any Office or public Trust under the United States." England had historically required office holders to swear an oath that they believed in essential doctrines of the Church of England, or of Protestantism more generally; several of the early American states had similar provisions. The Test Oath Clause prohibits any such requirement for federal office holders. Persons of any faith or of none may freely com- 
pete for federal office and hold the office if selected. But nothing prevents voters from considering religion when they vote, and nothing prevents the president from considering religion when he makes political appointments.

The more famous provision appears in the First Amendment to the Constitution: "Congress shall make no law respecting an establishment of religion or prohibiting the free exercise thereof." "Establishment" is a word that may not translate very well. I believe it is a cognate, and that in its general sense it means roughly the same thing in French and English. But as applied to religion, "establish" and "establishment" have a special sense in English. Early in the sixteenth century, King Henry VIII of England rejected the authority of the Pope, seized control of the structure and property of the Catholic Church in England, and had his Parliament enact a law making the King the head of the church. Later English legislation referred to this new church as "the Church of England by law established." From this statutory phrase came a new English usage: An established church, or an established religion, is one supported and sponsored by the government.

To say that "Congress shall make no law respecting an establishment of religion" is thus to say that Congress shall not support or sponsor religion. This provision is commonly called the Establishment Clause. To say that Congress shall make no law "prohibiting the free exercise" of religion is more straightforward; Congress shall not prevent churches or individuals from exercising, or actively practicing, the religion of their choice. This provision is commonly called the Free Exercise Clause. The Establishment and Free Exercise Clauses together are called the Religion Clauses.

By their terms, these guarantees apply only to federal offices and to the federal Congress. But constitutional amendments after the American Civil War (1861-65) are now understood to equally protect these rights from interference by state and local governments. This is called "incorporation"; the early constitutional provisions protecting rights against the federal government are said to be "incorporated" into the Fourteenth Amendment, which protects rights against states and against local governments, which are created by states. So the Test Oath Clause, the Establishment Clause, and the Free Exercise Clause are now fully applicable to state and local governments. ${ }^{2}$

In addition, even before the Civil War, states guaranteed religious liberty in their own constitutions. (American states have much more autonomy than

2. Torcaso v. Watkins, 367 U.S. 488 (1961); Cantwell v. Connecticut, 310 U.S. 296, 303 (1940). 
French provinces, and before the Civil War, states had far more autonomy than they do now. Each state has its own constitution and its own bill of rights.) These state constitutional provisions tend to be more detailed than the federal provisions. They are generally, but not always, similar in meaning.

Increasingly in recent years, there are state and federal statutes to protect religious liberty. Many of these statutes exempt religious practices from government regulation; they attempt to protect religious practice more effectively than the federal Free Exercise Clause.

The American legal system relies heavily on judicial precedent arising from the decision of individual cases. So these constitutional and statutory provisions are repeatedly interpreted by courts. In a process based on common law methods, these judicial opinions themselves become part of the law. The differences between state and federal Religion Clauses, or between statutes and the federal Free Exercise Clause, are only partly reflected in different constitutional and statutory text. To a great extent, these differences have emerged as differences in judicial interpretation. Judicial interpretation can change over time, in response to legal, political, social, or even religious developments. Judges can modify or overrule earlier judicial opinions; legislatures can amend the text of statutes. Constitutions can also be amended, but that is much more difficult.

\section{Some Essential History: Three Alignments of Religious Conflict}

\section{A. Protestant-Protestant Conflict: The Founding and Its Consequences}

The United States never had a dominant national church that exercised great power and provoked great reaction. No church in the United States has ever occupied anything like the place of the Catholic Church in France.

The story of church-state relations in the United States begins with the thirteen English colonies that later became the thirteen original states. Most of these colonies had an established church-a church sponsored and supported by the colonial government. In each case, the established church was a particular Protestant denomination.

The Church of England was established in five southern colonies and in parts of New York. In three New England colonies, the established church was chosen by local elections, which were nearly always won by the Congregational Church (the eighteenth-century descendants of the Puritans). These established churches did not have centuries of accumulated wealth. They did have a domi- 
nant social and political position; they were supported by taxes collected by the government; and they provoked substantial resentment. But their story has a very different ending from the story of the Catholic Church in France.

The dominant regional position of these two established churches was threatened by continued immigration of Protestants of many denominations. Members of the churches that were not established were called "dissenters," because they dissented from the teachings of the established church. Beginning in the 1740s, Baptists, Presbyterians, and other dissenters greatly increased their numbers in a surge of religious enthusiasm known as "The Great Awakening." Members of these dissenting churches were evangelical Protestants, more enthusiastic and less formal in their worship than the established churches, and more intense in their faith. They were the direct religious ancestors of the evangelical movement in the United States today.

In the wake of the American Revolution, each state and the new federal government wrote a constitution. The evangelical dissenters insisted that these new constitutions address issues of religious liberty. Immediately in most states, eventually in all states, the established churches were disestablished-deprived of government sponsorship and deprived of tax support. The details varied from state to state, but disestablishment was not the work of secular revolutionaries. It was mostly the work of evangelical religious dissenters.

In the free competition for religious adherents that followed, the formerly established churches did not fare well. The Congregational Church and the Episcopal Church (the new name for what was formerly the American branch of the Church of England), today retain a membership that is affluent and politically influential but small in numbers. Together, these formerly established churches are now only 2.4 percent of the population. ${ }^{3}$ The remaining 97.6 percent include a remarkable diversity of other Christian denominations and also a diverse array of non-Christian faiths, nonbelievers, and other secularists.

The dominant issue in the founding-era debate over disestablishment was government financial support for churches. Churches that received tax support did not want to give it up; many citizens, and especially dissenters and the unchurched, did not want to pay the taxes. Defenders of the established churches proposed as a compromise that dissenters be allowed to pay their church tax to

3. See Barry A. Kosmin, Egon Mayer \& Ariela Keysar, American Religious IdentificaTION SuRvey 2001, at 12 exh.1 (2001), available at http://www.gc.cuny.edu/faculty/research_ studies/aris.pdf. 
their own church, so that tax money would be equally available to all denominations. But in the end, every state rejected this compromise. This high-profile debate over tax support for churches has played a large role in the development of American understandings of religious liberty.

\section{B. Protestant-Catholic Conflict: The Nineteenth and Early-Twentieth Centuries}

The Catholic Church had a very small presence in the English colonies that became the United States. Even so, Americans inherited a fear of Catholicism from the English experience of Protestant-Catholic conflict. Beginning in the second quarter of the nineteenth century, and continuing until World War I, there was massive Catholic immigration to the United States, resulting in serious Protestant-Catholic conflict. This conflict raised two principal issues, closely related but distinct.

Both issues grew out of the treatment of religion in the public schools. Public schools in the United States are organized and operated by local governments and funded by state and local taxes; only since the 1960s has there been modest financial aid from the federal government. Creation of public schools was mostly a nineteenth-century development, largely coinciding with the Catholic immigration.

Most of these public schools in the nineteenth century attempted to teach the Bible and the basic principles of Christianity, and to do so in a way that avoided disagreements among Christian denominations. They did not wholly succeed in avoiding disagreements among Protestants, but Protestants suppressed their disagreements in the face of what they viewed as the Catholic threat. From a Catholic perspective, the religious teaching in the schools was clearly Protestant in its scriptural translations, in its ritual practices, and in its theological presuppositions.

Catholics responded with two demands. One was to eliminate Protestant teaching in the public schools; the other was that government pay for privately run Catholic schools. In the Catholic view, they were simply demanding equality. Government paid for public schools that were Protestant; it should also pay for schools that were Catholic.

Protestants denied that the public schools were Protestant. They said that the religious exercises in the public schools were "nonsectarian," by which they meant neutral as among Christians, but that Catholic schools were "sectarian," teaching the doctrines of a particular sect. Protestants also refused to provide 
government funding for the small number of schools run by Protestant denominations; these schools too were sectarian. But everyone understood that Catholics were the principal target of this distinction between sectarian and nonsectarian schools.

Protestants argued that the principle from the founding-that government should not financially support churches-also meant that government should not financially support sectarian schools. Applying this principle to schools was in fact a significant extension. Catholic schools taught religion, but they also taught reading, writing, mathematics, and other secular subjects. Government could have paid for instruction in secular subjects and let the church add its own funds to pay for religious instruction. But Protestants were numerically dominant, so solutions that would permit partial funding of Catholic schools were not seriously considered. Moreover, political parties found it in their interest to agitate this issue from time to time. A majority of state constitutions were amended to forbid government financial support for sectarian schools; in 1876, a similar proposed amendment to the federal Constitution was narrowly defeated in Congress.

There was also a large Jewish immigration to the United States in the latenineteenth and early-twentieth centuries. Of course, Jewish students also objected to Christian religious instruction in the public schools. The Jewish community's principal response, then and now, was to urge that the public schools be secularized. Most American Jews did not start their own schools, and those who did start schools did not seek government financial support.

World War I cut off the great flow of European immigration, and after the war, the United States restricted its resumption. Each succeeding generation of Catholics and Jews were more assimilated than their parents, and ProtestantCatholic tension gradually eased. In 1960, John Kennedy was the first Catholic to be elected president, and he and his family were personally attractive and widely popular. Shortly thereafter, the Second Vatican Council committed the Catholic Church to freedom of conscience. After these two events, lingering anti-Catholicism in the United States collapsed with remarkable speed. Even earlier, in 1955, a well-received book argued that Protestants, Catholics, and Jews were three great branches of a common civil religion in the United States. ${ }^{4}$

4. Will Herberg, Protestant-Catholic-Jew: An Essay in American Religious Sociology (1955). 


\section{Religious-Secular and Left-Right Conflict: The Late-Twentieth Century and Today}

Other fault lines were emerging even as Protestant-Catholic conflict dwindled. The 1960s were a decade of great social change in the United States and elsewhere. The civil rights movement, the antiwar movement, and the sexual revolution were concentrated in the 1960s. There were race riots in many American cities. The Supreme Court delivered libertarian decisions expanding the rights of free speech, of religious and racial minorities, and of criminal defendants. In 1973, the Court announced a constitutional right to abortion. ${ }^{5}$

These developments provoked a backlash, and part of that backlash was religious. Culturally conservative religious believers of all faiths-evangelical Protestants, conservative Catholics, Orthodox Jews-resisted the sexual revolution, the general attitude of permissiveness, and the sense of social disorder associated with demonstrations, crime, and riots; they were especially horrified by the right to abortion. What came to be known as the Religious Right is part of the political coalition that has elected a series of increasingly conservative American presidents, beginning with Ronald Reagan in 1980.

This backlash had consequences for competing views of religious liberty. For most of American history, the most theologically conservative Protestants had been the most anti-Catholic, and therefore, evangelical Protestants had been among the most vigorous opponents of government funding for religious schools. But beginning in the 1960s, these conservative Protestants began building religious schools of their own. This movement began in response to racial desegregation in the public schools, but that issue eventually faded. Conservative Protestant schools have grown dramatically in numbers and show every sign of permanence, sustained by parents who view the public schools as secularized and hostile to religious faith.

At first the leaders of these Protestant schools were more concerned with avoiding government regulation than with attracting government funding. But after the regulatory issues were mostly resolved, parents in these schools increasingly resented paying taxes for public schools they felt they could not use, while also paying the full cost of creating a private alternative. Their situation was exactly that of Catholic parents a century before. And in the 1980s, evangelical Protestants changed their minds about government funding for religious

5. Roe v. Wade, 410 U.S. 113 (1973). 
schools. Since then, government funding for private schools has drawn the support of a coalition of Catholics, evangelical Protestants, secular conservatives arguing the benefits of competition in a free market, and a minority of black parents seeking alternatives to inner-city public schools that are often of low quality. As we shall see, the Supreme Court has responded; it has changed its interpretation of constitutional law about funding religious schools.

In the 1980s and later, the religious division in the United States began to look more parallel to the historic religious division in France, with intense believers arrayed against secularists. ${ }^{6}$ But each side is a diverse coalition, difficult to accurately summarize. Both sides include people of many different faiths; the United States is further than ever from having a single dominant church. On one side are intensely religious, culturally conservative believers of all faiths. Conservative Protestants, Catholics, and Jews often find they have more in common with each other than with liberal adherents of their own religious tradition. These religious conservatives make effective alliances with secular conservatives in electoral politics and on issues of mutual interest. Occasionally, Muslims join in this coalition of the religiously conservative, but that collaboration was never well developed, and the tensions growing out of terrorist attacks and the invasion of Iraq have made Christian-Muslim cooperation more difficult for both sides.

On the left is a small but increasingly vocal population of nonbelievers, a large group of serious religious believers who are politically and theologically liberal, and a large group that I will call nominal believers. In opinion polls, 95 percent of Americans say they believe in "God or a universal Spirit." But many of those 95 percent rarely attend church and appear to act on a thoroughly naturalistic worldview in their daily life. This is the group I am calling "nominal believers"; for them, God appears to be a very remote being, a metaphor, or perhaps a polite fiction. The religious affiliations of these liberal believers and nominal believers also cross the traditional divides among Protestants, Catholics, and Jews.

There has emerged among this secular and religious-left coalition a new form of anti-Catholicism. Historic anti-Catholicism in the United States was based in Protestantism, in theological disagreements, and in hostility to the papacy. This historic Protestant anti-Catholicism is now confined to a barely

6. See generally James Davison Hunter, Culture Wars: The Struggle to Define America (1991); Phillip E. Johnson, Reason in the Balance: The Case Acainst Naturalism in Science, Law \& Education (1995). 
visible fringe. The new anti-Catholicism is based on resentment of the Church's efforts to enact certain Catholic moral teachings into law-especially on sexual behavior and abortion - and it is just as hostile to conservative Protestants as it is to conservative Catholics.

There are many smaller religious groups that do not neatly fit on either side of the main line of religious conflict. The United States once again has high immigration rates, and most of this immigration comes from places outside Europe. Many of these immigrants are Christian, but in the United States, they are so far distinguished more by their ethnic identity than by their religious identity. Many are Muslim; some are Buddhist, Hindu, or adherents of smaller religions from around the world.

Unusual variations of Christianity and Judaism have survived and sometimes flourished in the United States. A few of these preserve nineteenthcentury lifestyles (the Amish, for example); some are highly insular communities with unusual dress and customs (Hasidic Jews, for example); some live in quite conventional ways but have distinctive theologies (the Mormons, for example). There are groups such as the Hare Krishnas, the Scientologists, and the Unification Church, pejoratively called "cults" and euphemistically called "New Religious Movements." Perhaps a more neutral description is that they seem very strange to most Americans and they make high demands on their members.

These unusual religious groups, including the recent immigrants, produce a greatly disproportionate share of litigation about the free exercise of religion. The more mainstream groups, on either side of the division between religious conservatives and secularized liberals, produce most of the litigation about government support for religion. ${ }^{7}$

\section{Some Frequently Heard Concepts}

There have been many attempts to capture the essence of the American understanding of religious liberty in a word or a phrase. Some of these efforts have been used as political slogans; most of them have been analyzed and elaborated by academics. But there is no authoritative definition of these concepts, and no authoritative hierarchy among them, because the Supreme Court has not used them in any systematic way.

7. For a more detailed account of the constitutional effects of religious change, see John C. Jeffries, Jr. \& James E. Ryan, A Political History of the Establishment Clause, 100 Mich. L. Rev. 279 (2001). 
These phrases appear in Supreme Court opinions when convenient or helpful, and the Court has given some of them inconsistent meanings over time. These words indicate broad approaches rather than precise principles for deductive reasoning, and on many issues, each side tries to claim that its position is consistent with most of these approaches. Some of these terms attempt to distinguish conflicting positions, but many of them describe different aspects of the same reality. Do not exaggerate the importance of these terms. Still, I think it useful to introduce them before turning to more specific controversies.

\section{A. Separation}

Separation of church and state has a range of meanings. ${ }^{8}$ The narrowest meaning is institutional separation: Nearly all Americans agree that the institutions of the church should be separate from the institutions of the state. By general law the state provides legal structures under which churches can organize themselves; most churches are not-for-profit corporations, but some have trustees to hold their property, and some are unincorporated associations. Any church can organize itself under these structures; no form of license or advance permission is required, and the state has no voice in deciding which churches can exist, in appointing church personnel, or in developing religious doctrine. Conversely, no governmental powers can be delegated to a religious organization. ${ }^{9}$

Perhaps the most fundamental point of separation is that questions of religion are separated from the coercive power of government. Government cannot use its coercive power to support or oppose religion, either on its own initiative or at the request of a church.

Financial separation was established at the founding. Government does not financially support churches, and churches generally do not pay taxes. Church tax exemption is a legislative policy; it is constitutionally permitted ${ }^{10}$ but not constitutionally required." The remaining controversy over government financial support concerns whether and to what extent the ban on financial support applies to religious schools and social service providers.

8. Douglas Laycock, The Many Meanings of Separation, 70 U. CHI. L. Rev. 1667 (2003) (reviewing Philip Hamburger, Separation of Church and State (2002)).

9. See Bd. of Educ. v. Grumet, 512 U.S. 687 (1994); Larkin v. Grendel's Den, Inc., 459 U.S. 116 (1982).

10. Walz v. Tax Comm'n, 397 U.S. 664 (1970).

11. Jimmy Swaggart Ministries v. Bd. of Equalization, 493 U.S. 378 (1990). 
The most intense controversies are about the extent to which government functions must be separated from religious observance and ritual. For example, can government meetings open with prayer?

A longstanding minority in the United States interprets separation in a way that seeks to minimize the influence of religion. This minority sees any influence of religion on government as a contact that violates separation; they would exclude religious meetings from public places and religious arguments from political debate. This view has never attracted a majority of the Supreme Court; it is not a mainstream meaning of separation. But neither does it fade away.

\section{B. Voluntarism}

Nearly all Americans believe that religious belief and activity should be voluntary, and thus that government should not coerce it. A majority of the Supreme Court, and a minority of public opinion, believe that government should not encourage or discourage religious belief or practice even if it refrains from coercion. Voluntarism is closely related to separation. Separation is the more common phrase, but voluntarism is the older of the two ideas.

The dissenting Protestants in the founding era insisted on voluntarism as part of their attack on the established church. It is obvious why voluntarism appeals to dissenters and nonbelievers; if one does not wish to go to church (or to the established church), it is important for the state to recognize that religion should be voluntary. Less obviously, the idea of voluntarism originated with devout Protestants who concluded that coerced religious faith is ineffectual, so that it did no good to coerce people into church attendance. The religious rationale for voluntarism is that only voluntary religious commitments can please God or save souls.

\section{Equality}

The legal equality of all faiths was settled in the founding era, as a corollary of disestablishment. The established church was deprived of its preferred status, and all churches were guaranteed the same liberties. Those who accomplished this change were thinking mostly of the different Protestant denominations, but the principle has been extended to Catholics, Jews, and all the remarkably diverse faiths that have since appeared in the United States. In principle, and to a great extent in practice, this equal status for all faiths includes those high- 
demand religions that have drawn special regulation in some other countries, such as the Hare Krishnas and Scientologists. These small and unusual religions have the same rights as any other religious group. These groups have encountered some legal difficulties, mostly in the form of private lawsuits initiated by disgruntled former members, but they are not subject to any special regulation or supervision.

\section{Neutrality}

Religious neutrality is the appropriate government response to religious equality. The Supreme Court says that government should be neutral as between religious faiths, and that it should be neutral as between religion and religious disbelief. (The Court's usual phrase is neutral between "religion and nonreligion," but I think that "religious disbelief" better explains what the Court means by nonreligion.) There is very broad support for these propositions with respect to the coercive powers of government; Americans overwhelmingly agree that government should not penalize either believers or nonbelievers.

There is more controversy about neutrality with respect to government subsidies. Some Americans oppose any subsidy to any organization with a religious affiliation. Other Americans support subsidies to religious schools or social service providers, but tend to think that subsidies should be confined to religions that are not too different from their own. The Supreme Court's position is that subsidies to religious organizations are sometimes forbidden, but that when they are permitted, they must be equally available to all faiths, however unfamiliar.

The most controversial application of the Supreme Court's neutrality principle is to government expressions of opinion. The Court often says that government should express no views on religious questions-it should express no preference as between different faiths or between religion and religious disbelief. This rule is settled law with nar row exceptions, but a majority of Americans are unpersuaded.

Neutrality has also generated substantial arguments about what it means to be neutral. The Supreme Court usually speaks of neutrality without specifying a definition, and sometimes it shifts from one meaning to the other. Two principal meanings have been recognized. ${ }^{12}$

12. See Church of the Lukumi Babalu Aye, Inc. v. City of Hialeah, 508 U.S. 520, 559-64 (1993) (Souter, J., concurring). 


\section{Formal Neutrality}

Formal neutrality means government that is blind to religious differences. A law is formally neutral if it makes no distinctions on the basis of religion. Such a law applies equally to religious institutions and secular institutions, and it applies equally to the same conduct whether that conduct was done for religious reasons or secular reasons.

\section{Substantive Neutrality}

Substantive neutrality means that government seeks to govern in such a way that it neither encourages nor discourages religious belief or practice. Sometimes formal neutrality is also substantively neutral: If secular and religious speakers have equal rights to speak in the city park, government will treat them exactly the same (formal neutrality) and no one will be encouraged to make his message more or less religious (substantive neutrality). But supporters of substantive neutrality believe that, sometimes, neutrality requires government to take account of religious differences. A law that prohibits sex discrimination in employment, in most of its applications, regulates an unfair employment practice that has little or no commercial justification. But as applied to the employment of Catholic priests or Orthodox Jewish rabbis, such a law prohibits a religious practice, strongly discouraging that practice with threats of legal penalties. Exempting the employment of clergy permits the religious practice to continue, but it does not encourage anyone to become Catholic or to become an Orthodox Jew, nor does it encourage other churches to stop ordaining and employing women clergy. Exempting the religious practice may be more neutral in its effects than regulating religious and secular practices equally.

\section{E. Liberty}

Some American commentators say that the fundamental point of religious liberty is liberty, and that all the other concepts I have mentioned are instrumental at most, distractions at worst. The goal of guaranteeing religious liberty is to ensure that each American has as much liberty as possible to choose and act on his own religious commitments or his own rejection of religion. And some would say that we should pose that question directly-that the Court should seek to maximize religious liberty rather than separation, voluntarism, equality, or neutrality. 


\section{F. Toleration}

In the early years in some American colonies, as in Europe at the same time, the established church suppressed all other churches. This suppression of other faiths gave way to "toleration," in which one church was established and others were tolerated. "Toleration" implied subordinate status and toleration by the grace of the established church; these connotations soon became unacceptable. Disestablishment and the equality of all faiths marked the end of toleration as an acceptable account of religious liberty, and the word fell into disuse. In 1689, England's "Toleration Act" guaranteed toleration to all Protestants; a century later, America's First Amendment guaranteed "free exercise" of religion to all faiths, without limitation to Protestants. Although the word "toleration" is no longer used, we shall see that the idea lingers in disputes over government expression of religious opinion.

\section{G. State Action}

State action is a general constitutional concept, not specific to religious liberty, but it has special relevance to religious liberty. American constitutions create and regulate the branches of government, defining the powers of each. Constitutional rights limit what the government can do to the people; these rights do not limit what the people can do to the government, or to each other. Constitutional rights apply only to actions done by the government, or by someone exercising governmental authority; the usual phrase is that constitutional rights protect only against state action.

It is sometimes said that separation of church and state prevents churches from taking over the government, or even from unduly influencing the government. But the state action requirement means that the Constitution does not restrict the efforts of churches or religious individuals to influence the government. The Constitution applies only when the government itself takes action, whether on its own initiative or at the request of a church. Moreover, state action is the difference between protected free exercise and prohibited establishment. Religious conduct by private citizens is free exercise of religion; religious conduct by government is, in most cases, an establishment of religion. 


\section{Principal Disputes Over the Meaning of Religious Liberty}

Three great sets of practical issues produce persistent controversy over the meaning of religious liberty in the United States. Two of these controversies grow directly out of the nineteenth-century Protestant-Catholic conflict over schools: funding of religious schools, now generalized to funding of any religiously affiliated activity, and religious observances in public schools, now generalized to all religious speech with government sponsorship. The third great controversy, less publicized but in my view more fundamental, concerns regulation of religious practice. Organized interest groups on borh sides support lawsuits seeking to advance their views on each of these disputed issues, so there is a remarkable volume of litigation. I will try to keep jargon to a minimum, but it is impossible to explain legal developments in the United States without reference to the names of cases.

\section{A. Funding of Religiously Affiliated Activities}

The founding-era principle that government should not directly fund the religious functions of churches has survived with little disagreement for more than two hundred years. The nineteenth-century controversy over the funding of religious schools has continued unabated to the present, and is actually expanding in scope. To the extent that any funding is permitted, it is subject to the principle of equality of all faiths; government money must be available on equal terms to all. These settled principles-that government should not fund churches and that any funding of other religious organizations must be distributed on equal terms - distinguish the United States from much of Western Europe.

The political fight over government money for religious schools continued for more than a century before it reached the Supreme Court. In most places the opponents of funding won politically, so there were no funding programs to challenge in court. And it was not plausible to file a lawsuit challenging the absence of such programs; no one thought that government might be required to fund religious schools.

In the mid-twentieth century, as Protestant-Catholic conflict declined, a few states and localities began to enact modest programs of aid to private schools. Then in the 1960s, economic and social forces-especially the decline of central cities-threw the Catholic school system into financial crisis. Public education officials feared that Catholic schools might close in large numbers, returning 
many thousands of students to the public schools and causing a financial crisis there. The states most affected began searching for ways to give money to private schools, and the pace of litigation greatly accelerated.

The relevant law has changed dramatically over time as the Supreme Court responded first to one, then to the other, of two conflicting principles. In 1947, the Court announced these conflicting principles in consecutive paragraphs in the first modern Establishment Clause case, Everson v. Board of Education. ${ }^{13}$ On one hand was the no-aid principle: "No tax in any amount, large or small, can be levied to support any religious activities or institutions, whatever they may be called, or whatever form they may adopt to teach or practice religion." ${ }^{14}$ On the other was the nondiscrimination principle: Government "cannot exclude individual Catholics, Lutherans, Mohammedans, Baptists, Jews, Methodists, Nonbelievers, Presbyterians, or the members of any other faith, because of their faith, or lack of it, from receiving the benefits of public welfare legislation." 15

In the beginning, these two principles had been consistent. The eighteenthcentury debates involved earmarked taxes levied exclusively for the funding of churches. In an era with few public welfare benefits, these taxes funded purely religious programs and funded those programs preferentially. As applied to that dispute, the no-aid and nondiscrimination principles did not conflict, and the no-aid principle served religious liberty. No-aid protected citizens from being forced to contribute to churches involuntarily; it protected the churches from financial dependence on government, and thus from government control. It prevented discrimination in favor of religion, and it did not discriminate against religion. As I have said, there is still substantial consensus that government should not fund the religious functions of churches.

The modern cases are very different. In all the modern cases, government is funding some secular service-usually education, but sometimes medical care, care of neglected children, or some other social service. Government offers the money on equal terms to religious and secular providers alike. In that context, the Court had to choose between its two principles. Either government money would flow through to religious institutions, or students in religious schools, and patients in religious hospitals, would forfeit instruction or services that the state would have paid for if they had chosen a secular school or hospital.

13. Everson v. Bd. of Educ., 330 U.S. 1 (1947).

14. Id. at 16.

15. Id. (emphasis omitted). 
The nondiscrimination principle prevailed in Everson, which upheld government-funded bus rides to a Catholic high school - but by a 5-4 vote. Two decades later, the Court allowed states to provide secular textbooks for use in religious schools. ${ }^{16}$ Then the Court changed direction. In Lemon v. Kurtzman, ${ }^{17}$ in 1971, the Court struck down a funding program for the first time, holding that states could not subsidize teachers' salaries in religious schools. The no-aid principle predominated from then until 1985.

But even in this period, the no-aid principle never completely triumphed. Instead, the Court made many fine distinctions. It permitted government support for most religious colleges, ${ }^{18}$ but restricted aid to religious elementary and secondary schools. In the elementary and secondary cases, the Court drew distinctions that few observers would defend. The state could provide books, ${ }^{19}$ but not maps; ${ }^{20}$ it could provide bus rides to school, ${ }^{21}$ but not bus rides to field trips. ${ }^{22}$ Perhaps most absurd, the Court prohibited government-funded remedial instruction to lowincome students in religious schools, ${ }^{23}$ but permitted that same instruction in vans parked nearby. ${ }^{24}$ The cost of vans, and of dressing children to go back and forth in all weather between the school building and the vans, was a deadweight economic and educational loss, with benefits that were at most symbolic. This symbolism irritated the supporters of religious schools and completely failed to satisfy the objections of those who thought there should be no funding at all.

Few justices really believed in these awk ward distinctions. They emerged in part because the Supreme Court has nine justices who cast independent votes and often have difficulty agreeing. ${ }^{25}$ Some justices opposed nearly all aid to reli-

16. Bd. of Educ. v. Allen, 392 U.S. 236 (1968).

17. Lemon v. Kurtzman, 403 U.S. 602 (1971).

18. See Roemer v. Bd. of Pub. Works, 426 U.S. 736 (1976); Hunt v. McNair, 413 U.S. 734 (1973); Tilton v. Richardson, 403 U.S. 672 (1971).

19. Allen, 392 U.S. 236.

20. Meek v. Pittenger, 421 U.S. 349, 362-66 (1975), overruled in part by Mitchell v. Helms, 530 U.S. 793, 808 (2000) (plurality opinion with O'Connor, J., concurring in the overruling).

21. Everson v. Bd. of Educ., 330 U.S. 1 (1947).

22. Wolman v. Walter, 433 U.S. 229, 252-55 (1977), overruled in part by Mitchell, 530 U.S. at 808 (plurality opinion with O'Connor, J., concurring in the overruling).

23. Aguilar v. Felton, 473 U.S. 402 (1985), overruled by Agostini v. Felton, 521 U.S. 203, 235-36 (1997).

24. Wolman, 433 U.S. at 244-48; Walker v. San Francisco Unified Sch. Dist., 46 F.3d 1449 (9th Cir. 1995). Wolman has not been overruled on this point.

25. For analysis of why it is so difficult for the Court to render consistent decisions over time, see Frank H. Easterbrook, Ways of Criticizing the Court, 95 HaRv. L. Rev. 802 (1982). 
gious schools; some justices would have permitted nearly all aid to religious schools. And some justices searched for compromise, trying to permit some aid but not too much. Some of these justices in the middle were unwilling to overrule the earlier cases, preferring instead to draw artificial distinctions. And some of them were still trying to preserve each of the two competing principles of noaid and nondiscrimination.

Lemon v. Kuitzman, the case that prohibited state subsidies for teacher salaries, is famous for announcing a three-part legal test that is often quoted but rarely decisive. The Court said that for a statute to comply with the Establishment Clause, three things must be true:

First, the statute must have a secular legislative purpose; second, its principal or primary effect must be one that neither advances nor inhibits religion; finally, the statute must not foster "an excessive government entanglement with religion." 26

This test embodies the conflict between the no-aid and nondiscrimination principles. Its first two elements are taken almost verbatim from the Court's earlier explanations of "wholesome neutrality" toward religion. ${ }^{27}$ Its second element, prohibiting government actions that either advance or inhibit religion, is a statement of substantive neutrality. But in practice, justices invoking the Lemon test were much more concerned about government advancing religion than about government inhibiting religion. Through the 1970s and early 1980 s, the Court struck down most new forms of financial aid to religious schools. The Court used the second and third elements of the Lemon test to create a dilemma for legislators: any aid diverted to religious uses advanced religion, and any government monitoring to prevent such diversion caused excessive entanglement. The aid the Court permitted was generally said to be incapable of religious uses, such as secular textbooks, standardized testing, ${ }^{28}$ and diagnostic services. ${ }^{29} \mathrm{With}$ respect to the remedial instruction for low-income students, and other services provided by government employees to students in religious schools, the Court

26. Lemon v. Kurtzman, 403 U.S. 602, 612-13 (1971) (quoting Walz v. Tax Comm'n, 397 U.S. $664,674(1970))$.

27. Sch. Dist. v. Schempp, 374 U.S. 203, 222 (1963).

28. Comm. for Pub. Educ. \& Religious Liberty v. Regan, 444 U.S. 646 (1980); Wolman, 433 U.S. at 238-41.

29. Wolman, 433 U.S. at 241-44. 
implausibly said that the government employees providing these services were less likely to be drawn into religious discussions with the children if they were isolated in vans instead of working in a classroom of the religious school. ${ }^{30}$

Beginning in 1986, the Court progressively elevated the nondiscrimination principle and subordinated the no-aid principle. Since 1986, the Court has upheld six programs that permitted government funds to reach religious institutions ${ }^{31}$ it has invalidated none. Four decisions from the Lemon era have been overruled in whole or in part. ${ }^{32}$ The most important of the new decisions is Zelman $v$. Simmons-Harris, ${ }^{33}$ which upheld vouchers that can be used to pay tuition at any public or private school, including religious schools. These vouchers represent a right to draw on government funds for the exclusive purpose of paying educational expenses. The government issues the vouchers to individual students or their parents, who spend them at the school of their choice; the school then redeems the vouchers and collects the government money. Zelman reasons that the government is not responsible for any resulting benefit to religion. The government supports the student; the student and his parents decide where to spend the money, and there is no state action in their choice of a school. If they choose a religious school, that is a private decision. The Court has also upheld long-term loans of equipment to private schools, including religious schools, if the equipment is distributed to all schools on the basis of enrollment. ${ }^{34}$

Lemon's ban on direct cash grants to religious institutions remains in effect. And the Court would be much more cautious about programs in which the government exercises discretion in deciding which private schools get government money. American law tends to presume that such discretion will be abused where sensitive constitutional rights are at stake-that favored religions will get money and minority religions will not. But at least in the school context, there is

30. Id. at 247 .

31. Zelman v. Simmons-Harris, 536 U.S. 639 (2002) (school voucher program); Mitchell v. Helms, 530 U.S. 793 (2000) (federal aid to state education agencies which goes, in part, to parochial schools); Agostini v. Felton, 521 U.S. 203 (1997) (public school teachers providing remedial education in parochial schools); Zobrest v. Catalina Foothills Sch. Dist., 509 U.S. 1 (1993) (interpreters for the deaf); Bowen v. Kendrick, 487 U.S. 589 (1988) (grants for teenage sexuality counseling); Witters v. Wash. Dept. of Servs. for the Blind, 474 U.S. 481 (1986) (state vocational rehab for the blind).

32. See cases cited supra notes $20,22, \& 23$. The fourth case is School District of Grand Rapids $v$. Ball, 473 U.S. 373 (1985), overruled in part by Agostini, 521 U.S. 203.

33. Zelman, 536 U.S. 639.

34. Mitchell, 530 U.S. 793. 
no reason for legislatures to authorize either direct cash grants or discretion in distributing funds. They can deliver as much money as they are willing to spend in the form of vouchers to students and their families.

The voucher decision means that a long political tradition of no government aid to religious schools has given way to a constitutional rule that permits such aid in essentially unlimited amounts, so long as certain formalities are observed. But courts do not enact programs or appropriate funds; Zelman gives voucher supporters only the chance to fight further battles in Congress and in the states. They face a broad coalition of voucher opponents: church-state separationists, teachers' unions and others who fear that resources will be diverted from public schools, fiscal conservatives who oppose new entitlements and the taxes to pay for them, and suburban parents who fear that voucher programs will open suburban public schools to low-income students who might be disruptive. No state has enacted a general voucher program for all students in elementary and secondary schools. Voucher programs remain mostly experimental and concentrated on low-income students or students in schools that fail to meet educational standards.

Even these narrow programs are routinely challenged under the relevant state constitution. Many state constitutions have detailed restrictions on financial aid to sectarian schools. Some state courts have upheld such programs, generally following the reasoning of the United States Supreme Court; ${ }^{35}$ other state courts have held that such programs violate the state constitution. ${ }^{36}$

Supporters of aid programs have tried to achieve one more step in the federal courts. In a variety of specialized circumstances, some states aid secular private education but not religious private education. It was once thought that extending these programs to include religious education would violate the federal Establishment Clause, but after Zelman, that is clearly not true. And the Supreme Court generally says that government cannot discriminate against religion. So voucher supporters have begun to argue that states violate the Free Exercise Clause when they fund secular private education but refuse to fund similarly situated religious education.

The Supreme Court rejected that claim in the first case to present the question, Locke v. Davey. ${ }^{37}$ The federal constitutional rule now appears to be that

35. Kotterman v. Killian, 972 P.2d 606 (Ariz. 1999); Simmons-Harris v. Goff, 711 N.E.2d 203, 211-12 (Ohio 1999); Jackson v. Benson, 578 N.W.2d 602 (Wis. 1998).

36. Bush v. Holmes, 919 So. 2d 392 (Fla. 2006); Witters v. State Comm'n for the Blind, 771 P.2d 1119 (Wash. 1989).

37. Locke v. Davey, 540 U.S. 712 (2004). 
government funding of religious schools is permitted but not required, and that with respect to funding, government is permitted to discriminate against religion. Despite the traditional suspicion of government discretion in American constitutional law, government now has substantial discretion to fund religious education, or not to fund it, or even to fund it on condition that the student or the school comply with special regulations that apply only to those who accept government money. In part the Court deferred to the long American tradition of not funding religious institutions, treating that tradition as legitimate, although not constitutionally required. In part the Court deferred to the legislature's primary responsibility for allocation of government funds. Parts of the opinion suggest that its rule is confined to programs for the training of clergy; other parts of the opinion suggest that it will apply generally to any exclusion of religious institutions from state funding programs. New cases are already pending that present questions about the scope of Locke v. Davey.

For most of the twentieth century, this dispute over funding religious institutions was confined to schools. Religious hospitals and social service agencies received government funds with little controversy. That has changed with recent proposals for what is sometimes called "charitable choice," or in the Bush administration, its "faith-based initiative." These proposals, only some of which have been enacted, increased the visibility of government grants to religious charities, and they introduced new protections for the autonomy of religious charities accepting government funds. Agencies making grants would be forbidden to discriminate against religious charities; religious charities would not have to be separately incorporated from their sponsoring churches; and religious charities could retain their right to hire employees of their own faith even if they accepted government funds. Some of these protections are significant changes from traditional practice; some appear to be mostly symbolic. The proposed employment rules resolve an existing ambiguity in favor of the religious charities. Each of these proposed changes has been politically controversial; there are continuing fights in Congress, and there is pending litigation.

Zelman and other recent cases on funding schools suggest that there is no constitutional barrier to government funding of religious charities. But some social services may require direct grants to agencies instead of vouchers to the intended beneficiaries, because legislators will be reluctant to give vouchers to neglected children, the mentally ill, or the drug addicted, and tell them to choose their own service providers. And these programs are not so well funded that government can support all providers of services; government has to choose 
which agencies to support. So these programs may present questions of discretionary direct grants to religious charities, questions that can be avoided in the school cases. And there will certainly be litigation over the right of the religious charity to hire persons of its own faith for government-funded positions. ${ }^{38}$

In short, the long-running American dispute over government funding of religiously affiliated activities continues. New issues continue to emerge, and issues that are settled in one forum become the subject of renewed dispute in other forums. It is settled that the government cannot fund the core religious functions of the church; how far that principle extends to other functions is the subject of continuing dispute.

\section{B. Religious Speech, With and Without Government Sponsorship}

Prayer and other religious observances at government functions, and government displays of religious symbols, have given rise to an intense and peculiarly American set of controversies. This dispute began with ProtestantCatholic conflict over religious instruction in the public schools, and schools are still at the heart of it, but the dispute has spread to prayer at government meetings and to religious displays in city parks and on courthouse lawns.

No such issues were debated in the founding period. There was probably more religious rhetoric in government affairs then, and many government meetings were opened with prayer. On the other hand, gratuitous government displays of religious symbols were probably rare, and public schools did not exist. The nation was overwhelmingly Protestant, and the disagreements among Protestant denominations were not great enough to make prayers by the established clergy seriously objectionable to evangelical dissenters.

In the nineteenth century, as we have seen, Protestant religious observances in public schools gave rise to bitter controversy between Protestants and Catho-

38. The most complete descriptions and analyses of these programs and pending proposals appear in Ira C. Lupu \& Robert W. Tutrle, The State of the Law-2005: Legal. Developments Affecting Partnerships Between Government and Faith-Based Organizations (2005); Ira C. Lupu \& Robert W. Tuttle, The State of the Law-2004: Partnerships Between Government and Faith-Based Organizations (2004); Ira C. Lupu \& Robert W. Tuttle, The State of the Law2003: Developments in the Law Concerning Partnerships with Religious Organizations (2003); Ira C. Lupu \& Robert W. Tuttle, Government Partnerships with Faith-Based Service Providers: State of the Law (2002). These books are all available at The Roundtable on Religion and Social Welfare Policy, Roundtable Legal Publications, http:/www.religionandsocialpolicy.org/ legal/legal_publications.cfm (last visited Apr. 12, 2006). 
lics. Late in the nineteenth century, a small but vocal group of secularists sought to eliminate all government support for religion, including prayer and Bible reading. ${ }^{39}$ Recognizing that religious observances in the schools had become divisive, a few state courts and local school boards began to restrict them. ${ }^{\text {"1 }}$ Religious instruction in the public schools very slowly declined over a period of decades.

In a pair of famous decisions in 1962 and 1963, the Supreme Court held that public schools violate the Establishment Clause when they lead students in prayer or Bible reading. ${ }^{41}$ These decisions coincided with increasing acceptance of Catholics and Jews as fully equal and welcomed citizens, and perhaps-this is much harder to measure- - with more of the population drifting toward secularism or nominal belief. But by 1962, Protestant-Catholic tension had declined so far that Catholics no longer objected to prayer and Bible reading in public schools.

The school prayer decisions were unpopular and difficult to enforce. The decisions outraged evangelical Protestants, who feel called to teach the Christian gospel to all humans, and who feel the need to seek God's blessing and guidance for any important activity, including education and government meetings. The school prayer decisions were a prime contributor to the religious backlash in the 1960 s and later, and to the growth of private evangelical schools. At the same time, these decisions raised expectations among Jews and other non-Christian religious minorities, and among nonbelievers and other secularists, that they would no longer be subjected to government-sponsored Christian religious observances.

The result has been an escalating series of provocations and legal claims from both sides. There have been innumerable proposals to amend the Constitution to permit school-sponsored prayer, none of which has passed Congress, and endless efforts to restore school-sponsored prayer while disguising and denying government sponsorship. The Supreme Court has held that teachers cannot invite students to lead the prayer, ${ }^{42}$ and that school boards cannot conduct student elections to decide whether to have a prayer. ${ }^{43}$ The original cases in-

39. See Laycock, supra note 8 , at 1683-84.

40. Early court decisions are collected in School District of Abington Tounship v. Schempp, 374

U.S. 203, 275 n.51 (1963) (Brennan, J., concurring).

41. Schempp, 374 U.S. 203; Engel v. Vitale, 370 U.S. 421 (1962).

42. Karen B. v. Treen, 653 F.2d 897 (5th Cir. 1981), aff d mem., 455 U.S. 913 (1982).

43. Santa Fe Indep. Sch. Dist. v. Doe, 530 U.S. 290 (2000). 
volved prayer in classrooms, but more recently the Court has invalidated prayer at graduation and at athletic events. ${ }^{4+}$ The Court has refused to invalidate prayer at legislative sessions, ${ }^{45}$ principally because of long tradition: Congress had always opened its sessions with prayer, even in the First Congress, which had proposed the Establishment Clause.

The secular side opened a second front when it began challenging government-sponsored religious displays. The Supreme Court has held that public schools cannot display the Ten Commandments in classrooms, ${ }^{46}$ and that a county cannot display a Nativity scene (a three-dimensional depiction of the events immediately following the birth of Christ) at a central location in its courthouse. ${ }^{47}$ But it permitted a Nativity scene displayed alongside "secular" symbols of Christmas, such as Santa Claus, reindeer, and candy canes ${ }^{48}$ and it permitted a menorah (the principal symbol of the Jewish celebration of Hanukkah), next to a Christmas tree and a salute-to-liberty sign. ${ }^{+9}$ Most recently, the Court decided that Texas can maintain a large granite monument displaying the Ten Commandments on the lawn of its state capitol, ${ }^{50}$ but that two Kentucky counties cannot display the Ten Commandments on courthouse walls, surrounded by patriotic documents and a statement claiming that the Commandments are the foundation of the western legal tradition. ${ }^{51}$ Both decisions were 5 4; only Justice Breyer supported both results. He approved the Texas display mostly because it had been in place for forty years before it first aroused controversy; this suggested, at least to him, that the display contained both a religious and a secular message and that the secular message had predominated in public perception. He joined in the Court's opinion rejecting the much more recent Kentucky displays, in substantial part because local politicians had clearly stated their purpose to promote Christianity.

As the facts of these cases suggest, this legal and cultural battle is beginning to appear absurd. Each side aggressively pushes its position as far as logic will take it; each side takes advantage of every ambiguity in the Court's opinions.

44. Id.; Lee v. Weisman, 505 U.S. 577 (1992).

45. Marsh v. Chambers, 463 U.S. 783 (1983).

46. Stone v. Graham, 449 U.S. 39 (1980).

47. County of Allegheny v. ACLU, 492 U.S. 573 (1989).

48. Lynch v. Donnelly, 465 U.S. 668 (1984).

49. Allegheny, 492 U.S. 573.

50. Van Orden v. Perry, 125 S. Ct. 2854 (2005).

51. McCreary County v. ACLU, 125 S. Ct. 2722 (2005). 
The ambiguities result from the Court's unwillingness to enforce an absolute rule. The Court has said that government cannot endorse religion or any religious teaching, but the Court will not carry that rule to its logical conclusion. The results would be too unpopular, do too much damage to the Court's credibility, and do too little good for religious minorities and nonbelievers. The Court will not order presidents to stop issuing Thanksgiving proclamations; it will not order the government to remove "In God We Trust" from the coins and the currency; it certainly will not order changes to all the religious place names that Spanish friars scattered across the American Southwest, from San Francisco to Santa Fe to Corpus Christi. The Court will not entirely ban government participation in the nation's celebration of Christmas. But the Court cannot draw a principled line between the modest religious statements it permits government to make and the longer or more sectarian statements that it will not permit government to make.

To avoid ordering an end to government celebration of Christmas, the Supreme Court said that Christmas is both a religious and a secular holiday. ${ }^{52}$ The Court said that government can celebrate the secular aspects of the holiday, and that it would be discriminatory for government to celebrate only the secular aspects, so the government can mix religious and secular symbols of Christmas. But it cannot display religious symbols alone..$^{53}$ Nobody likes that compromise, but to the Court, the alternatives seemed worse.

You can now begin to see why the two Kentucky counties claimed that the Ten Commandments are the foundation of the western legal tradition. The counties claimed they had displayed the Commandments for their secular legal significance, not their religious significance. And they claimed that their display, like the Christmas displays the Court upheld, combined religious and secular documents. The claim that the Commandments were displayed for their secular legal significance and not for religious reasons was undoubtedly a lie, and it was based on an absurd reading of legal history. But the counties' real hope was that the Court would accept their rationalizations because the Commandments hanging on a courthouse wall might seem insignificant, not worth the inevitable cost of hostile public reaction to a decision ordering them removed. There were people on both sides who wished this lawsuit had never been brought- - but who

52. Lynch, 465 U.S. 668.

53. Allegheny, 492 U.S. 573. 
also thought, once it was in the Supreme Court, that it was important for their side to win.

The underlying conceptual disputes in these cases are about the scope of the government's obligation to be neutral. Opponents of government-sponsored prayers and religious displays say that government must be neutral as between religion and disbelief, and that government must be neutral in all that it says, even if no one is coerced. Some supporters of government prayers and religious displays concede that government should be neutral as between religions, so that government prayers and displays should refer to God only in general terms, and should avoid the specifics of different faiths. But they deny that government has any obligation to be neutral as between religion and disbelief. This is a modern version of the nineteenth-century position that government should teach "nonsectarian" religion in the public schools.

But of course many of these prayers and religious displays are not neutral as between religions. They are mostly Christian, and they tend to reflect evangelical Protestant beliefs and sensibilities. The deeper position of people who support government prayers and religious displays is that government need be neutral only when it exercises its coercive powers; government need not be neutral in what it says. Supporters of government expressions of religious belief say that government can promote religious belief so long as it does not punish people who decline to participate.

The Supreme Court has rejected this position at two levels. First, the Court says that if there is a public event that many people wish to attend for secular reasons, and then someone offers a prayer at that event, persons who attend are effectively coerced to participate in the prayer. ${ }^{54}$ But that argument goes only so far; it is hard to find coercion in the case of a passive religious display. Whether or not there is coercion, the Court says government may not "endorse" a religious viewpoint. ${ }^{55}$ Government must be neutral even in what it says about religion. This argument-whether the Establishment Clause restricts government endorsement or only government coercion-is at the heart of the dispute over government-sponsored prayer and religious displays. It is mostly irrelevant to other religious liberty issues.

54. Lee v. Weisman, 505 U.S. 577 (1992).

55. Santa Fe Indep. Sch. Dist. v. Doe, 530 U.S. 290, 308 (2000); Allegheny, 492 U.S. at 592-94; Wallace v. Jaffree, 472 U.S. 38,56 (1985). 
Those who support government prayers and religious displays are essentially urging a return to toleration as the measure of religious liberty, although they rarely argue the point in those terms. The dominant view among evangelical Christians is that minority religions and nonbelievers should be fully protected from penalties and civil disabilities, with full protection for the free exercise of minority religions. But evangelicals also think that religion should be included in all important government functions, that of course the religion included will be broadly consistent with the majority's religious beliefs, and that no one could reasonably expect otherwise. Religious dissenters do not have to attend formal worship services, but if they want to attend public meetings, or send their children to public schools, supporters of government prayer say that of course they should have to sit through brief observances of the majority religion. In that sense, the majority religion would be preferred and supported by government, and all other religions would be tolerated.

Although the Supreme Court tightly restricts government-sponsored religious speech, it vigorously protects religious speech by private citizens. Religious speakers have full rights of free speech, even in public schools or on government property, so long as they act voluntarily and without government sponsorship. "No government sponsorship" means they must be treated the same as other speakers; they cannot be given special access to facilities or to audiences assembled by the government. This right to religious free speech means that student prayer clubs can meet in empty classrooms on the same terms as secular student clubs, ${ }^{56}$ that students can urge their classmates to attend church or accept $\mathrm{Chris-}$ tianity, and that religious groups-even the Pope-can hold services or offer Mass in public parks to the same extent that secular groups can hold meetings or rallies. ${ }^{57}$ The Court has never held, in any context, that religious speech by private persons is subject to greater censorship or restriction because of its religious content.

The Court's restriction of government speech about religion, and its protection of private speech about religion, have been remarkably stable and persistent. But from 1994 to 2005, these two rules actually had the support of only two justices, Kennedy and O'Connor. Justices Rehnquist, Scalia, and Thomas would have permitted significant government sponsorship of religious speech, and Jus-

56. E.g., Good News Club v. Milford Cent. Sch., 533 U.S. 98 (2001); Bd. of Educ. v. Mergens, 496 U.S. $226(1990)$.

57. Fowler v. Rhode Island, 345 U.S. 67 (1953); O' Hair v. Andrus, 613 F.2d 931 (D.C. Cir. 1979). 
tices Stevens, Souter, Ginsburg, and Breyer would have imposed significant restrictions on private religious speech in public places. This persistent division on the Court enabled Kennedy and O'Connor to prevail; they generally had six votes to prohibit government sponsorship of religious speech, and at least five votes to invalidate government discrimination against private religious speech. But now of course, Rehnquist and O'Connor are gone. If President Bush has accomplished what he hopes with his first two appointments, Kennedy may be the new swing vote on these issues. And Kennedy had one important disagreement with O'Connor: He distinguished government-sponsored religious displays, which passers-by may just ignore, from government-sponsored religious exercises, which often trap a captive audience and which he generally voted to strike down. Eventually there will be more new justices, and these rules may change in more dramatic ways, just as the rules on funding of religious activities changed.

Many of the same political forces that support government funding of religious schools also support government-sponsored prayers and religious displays. In each of these disputes, much of the religious and conservative coalition is aligned against the secular and liberal coalition. Why has the Court changed its mind on funding, but not on prayers and religious displays?

The explanation again lies with Justices Kennedy and O'Connor, who see these two sets of cases as very different. The difference is best explained in terms of individual choice. In the funding cases, each family gets a voucher and each family can decide where to spend that voucher. Each family can choose a religious school or a secular school. In the private religious speech cases, each speaker can decide what to say and each person around him can decide whether to listen. Each student can decide whether to attend the meetings of the student prayer club.

But prayer at a government meeting, or a religious display in a government building, requires a collective decision. Either there will be prayer for everyone present, or a prayer for no one present. If there is a prayer, there will be only one, and it will be in a form more consistent with some religious traditions than with others. Either some government official must decide, or he must appoint someone to decide, and the person appointed will become a temporary agent of the government for that limited purpose. Everyone at the meeting will participate in, or at least politely sit through, the prayer that some government agent wrote or selected. No one gets to make an individual choice about whether to pray or how to pray.

Protecting individual choices about religion, and precluding government choices about religion, is consistent with nearly all the concepts used to describe 
religious liberty in the United States-with separation, voluntarism, equality, neutrality, and liberty. I think Justices Kennedy and O'Connor best implemented the American conception of religious liberty by permitting vouchers, protecting religious free speech, and restricting government prayers and religious displays. But in the current alignment of religious conflict in America, Kennedy and O'Connor have few supporters among politicians and interest groups. One side wants funding for private religious schools and prayer in public schools; the other side wants neither.

\section{Regulation of Religious Practice}

The final set of important and contested religious liberty issues is regulation of religious practice. In my view, this is the most fundamental and the least understood of the three sets of issues. It is most fundamental because it is only in these cases that individuals can be threatened with civil or criminal penalties for practicing their religion. It is least understood because the cases come in far greater factual variety than the funding cases or the government-sponsored religious speech cases, because many of the cases arise from nonrecurring conflicts between odd religious practices and odd regulations, because many of the victims are from small and little known religious groups and many of the burdensome regulations are equally obscure. The press finds these cases harder to report; the public finds it harder to take sides. But for fifteen years now, intense disagreement over these cases has divided the Supreme Court, divided the Court from Congress, and divided state legislatures. I will try to say enough about the facts of each case to give you a more concrete sense of these varied disputes.

From 1963 to 1990, the Supreme Court said that when a government regulation burdens a religious practice, government must either exempt the religious practice from the regulation, or show that applying the regulation to the religious practice is necessary to serve a compelling government interest. The first such case in the modern era was Sherbert $v$. Verner, ${ }^{58}$ which held that a state could not refuse unemployment compensation to a Sabbatarian who lost her job because she was unavailable for work on Saturdays. In Wisconsin $v$. Yoder, ${ }^{59}$ the Court held that a state could not require Amish children to attend high school when their parents preferred to educate them on Amish farms. Educating chil-

58. Sherbert v. Verner, 374 U.S. 398 (1963).

59. Wisconsin v. Yoder, 406 U.S. 205 (1972). 
dren might reasonably have been thought to be a compelling government interest, but the Amish were willing to send their children to public school through eighth grade, and Wisconsin required attendance only to age sixteen, which most children reach in the middle of tenth grade. The Court found no compelling advantage in that marginal increment to academic education as compared to Amish vocational education.

Despite these decisions, the Court did not actually exempt many religious practices from regulation. Prison and military regulations were subject to much more deferential standards. Deferring to prison authorities, the Court held that state prisons need not exempt Muslims from work assignments scheduled at the same time as a weekly Muslim worship service. ${ }^{60}$ Deferring to military authorities, the Court held that the Air Force did not have to allow a Jewish officer to wear a yarmulke with his uniform. ${ }^{61}$ The Court found a compelling interest in enforcing the military draft, so it allowed Congress to define the scope of conscientious objection, exempting those who objected to war in any form but not those who distinguished between just and unjust wars. ${ }^{62}$ The Court found a compelling interest in collecting taxes, so it refused to exempt Amish employers and employees from the social security tax, even though they objected to social insurance schemes and refused to accept social security benefits. ${ }^{63}$ The Court found a compelling interest in prohibiting racial discrimination in education, so it upheld a law refusing tax exemptions to private religious schools that discriminated against black students. ${ }^{64}$

I think these findings of compelling interest were entirely plausible; in each of these cases, there were reasons of secular self-interest to falsely claim the religious exemption, or even to genuinely convert to the religious belief that was entitled to the exemption. An exemption in these circumstances would thus encourage other citizens to join the exempted religion, and it would tend to greatly inflate the number of claims to exemption. But some commentators think these interests were not compelling, and that these cases suggest that the Court was not really serious about exempting religious behavior from nonessential regulation.

60. O' Lone v. Estate of Shabazz, 482 U.S. 342 (1987).

61. Goldman v. Weinberger, 475 U.S. 503 (1986).

62. Gillette v. United States, 401 U.S. 437 (1971).

63. United States v. Lee, 455 U.S. 252 (1982).

64. Bob Jones Univ. v. United States, 461 U.S. 574 (1983). 
In 1990, in Employment Division v. Smith ${ }^{65}$ the Court changed the rule. In Smith, the state had refused unemployment compensation to two workers who were discharged for consuming peyote, an hallucinogenic drug, at an American Indian religious ceremony. This ceremony, and the religion organized around it, has been part of American Indian practice in western North America since before the European settlement. The drug is relatively safe but not absolutely so; it has little recreational market; its religious use is associated with a decline in abuse of alcohol and other drugs among American Indians. ${ }^{66}$ These facts cast doubt on the government's claim of compelling interest in prohibiting the peyote religion. But in the Court's new view, none of those facts mattered.

Smith introduced an additional requirement for litigants seeking religious exemptions: Is the law that burdens religious exercise "neutral" and "generally applicable"? If so, the burden on religion apparently requires no justification whatever. If not, the burden on religion is subject to the compelling interest test as before. The Court said that Oregon's ban on peyote was neutral and generally applicable, so it could be enforced against the Indian religious ceremony without regard to the religious importance of the ceremony or the regulatory importance of the law.

For convenience, call the rule from 1963 to 1990 the Sherbert rule, and call the new rule, announced in 1990, the Smith rule. Under the Sherbert rule, the religious claimant must prove a burden on his religion; government must then prove that it has a compelling interest in imposing that burden. Under the Smith rule, there is a third element. The religious claimant still must prove a burden on his religion; the court must decide whether the law imposing the burden is neutral and generally applicable; and only if the law is not neutral, or not generally applicable, must the government prove that it has a compelling interest in burdening the religious practice.

Since Smith, the Supreme Court has decided only one case under the Smith rule-a case called Church of the Lukumi Babalu Aye, Inc. v. City of Hialeah ${ }^{67}$ Lukumi involved an Afro-Caribbean religion that sacrifices small animals, mostly goats and chickens, to its gods. Hialeah, a Florida city near Miami, prohibited the "sacrifice" of animals. The city argued that it had enacted a generally applicable ban on sacrifice. The church argued that the ordinances were a ban

65. Employment Div. v. Smith, 494 U.S. 872 (1990).

66. See Douglas Laycock, The Remnants of Free Exercise, 1990 Sur. Cт. Rev. 1, 7-8.

67. Church of the Lukumi Babalu Aye, Inc. v. City of Hialeah, 508 U.S. 520 (1993). 
on killing animals for religious reasons, carefully drafted so as not to prohibit any killings of animals for secular reasons. The Court unanimously agreed with the church, holding that the ordinances were neither neutral nor generally applicable, and that they served no compelling government interest. Lukumi gives substance to Smith's requirements of neutrality and general applicability, but the meaning of those requirements remains sharply disputed.

Government lawyers claim that nearly every law is neutral and generally applicable, and that the only exceptions are laws deliberately designed to single out a religious practice. This argument has some support in the facts of Lukumi, and some support in the language of the Smith and Lukumi opinions. Lawyers for religious claimants say that to be "generally applicable," a law must apply to all examples of the regulated conduct, without exceptions - or at least, with very few exceptions. On this view, many laws fail the requirement of general applicability, and thus are subject to the requirement of compelling government interest. This argument has some support in the facts of Smith, more support in the language of the Smith and Lukumi opinions, and much support in the way those opinions explain Sherbert and other earlier cases that have not been overruled. The Court in Smith and Lukumi distinguished these earlier cases, which means it gave them new explanations to show that their results were consistent with the Smith rule.

If the government lawyers are right, the Smith rule provides very little protection for religious liberty. Unless government is both hostile and clumsy, it can find a way to prohibit religious practices without openly singling out religion for special regulation, and thus without getting caught under the government understanding of the Smith rule. If the lawyers for religious organizations are right, the Smith rule provides substantial protection for religious liberty, but that protection is less inclusive, more complicated, and harder to invoke than the protection of the Sherbert rule. Either way, religious liberty is less protected under Smith than under Sherbert.

This reduction in protection for religious liberty provoked widespread disagreement among other branches and levels of government. Congress enacted the Religious Freedom Restoration $\mathrm{Act}^{68}$ (RFRA) in an attempt to restore the Sherbert rule as a matter of statutory right.

68. Religious Freedom Restoration Act of 1993, 42 U.S.C. $\$ \S 2000 \mathrm{bb}$ to $2000 \mathrm{bb}-4$ (2000), amended by Religious Land Use and Institutionalized Persons Act of 2000,42 U.S.C. $\$ \S 2000 \mathrm{cc}$ to $2000 \mathrm{cc}-5$ (2000). 
The Supreme Court held RFRA, as applied to the states, invalid as beyond the powers delegated to Congress. ${ }^{69}$ But RFRA remains in effect as applied to the federal government, ${ }^{70}$ and Congress has actually strengthened it. ${ }^{71}$ The first Supreme Court case interpreting RFRA gave the statute full and vigorous scope. ${ }^{72}$ The case involved religious use of hoasca, a tea brewed from two Brazilian plants and containing small quantities of a hallucinogenic drug prohibited by the Controlled Substances Act. The tea has effects similar to those of peyote. RFRA expressly puts on government the burden of proving its compelling interest in individual applications of federal law to religious practice. The Court unanimously held that the government had not carried its burden, and it unanimously rejected the government's claim that it need only point to Congressional fact finding in the course of enacting the Controlled Substances Act. The government's interpretation would have nullified RFRA's allocation of the burden of proof; the Court's holding makes RFRA an important protection for religious liberty.

Thirteen states have adopted state RFRAs, and at least another twelve states-arguably as many as seventeen states-have interpreted their state constitutions in ways more consistent with the Sherbert rule than with the Smith rule. ${ }^{73}$ So in one way or another, a majority of states have rejected the $S$ mith rule. But there has been remarkably little state-court litigation under these provisions, so the seriousness of state commitment to the Sherbert rule has not yet been tested.

Most recently, Congress enacted the Religious Land Use and Institutionalized Persons Act (RLUIPA). ${ }^{74}$ RLUIPA protects churches against local zoning laws that often make it difficult for new churches to buy or rent a place of worship. It applies only when the real estate transaction would affect interstate commerce, or when the zoning law is administered in an individualized rather than a gener-

69. City of Boerne v. Flores, 521 U.S. 507 (1997).

70. Christians v. Crystal Evangelical Free Church (In re Young), 141 F.3d 854 (8th Cir. 1998).

71. The exercise of religion protected by RFRA is defined to include "any exercise of religion, whether or not compelled by, or central to, a system of religious belief." 42 U.S.C. $\S 2000 \mathrm{cc}-5(7)$ (2000); see also 42 U.S.C. $\$ 2000 \mathrm{bb}-2$ (4) (2000).

72. Gonzalez v. O Centro Espirita Beneficente Uniao do Vegetal, 126 S. Ct. 1211 (2006).

73. These state laws and decisions are collected in Douglas Laycock, Theology Scholarships, the Pledge of Allegiance, and Religious Liberty: Avoiding the Extremes but Missing the Liberty, $118 \mathrm{H}_{\mathrm{ARv}}$. L. REv. 155, 211-12 (2004).

74. Religious Land Use and Institutionalized Persons Act of 2000, 42 U.S.C. $\$ \S 2000 \mathrm{cc}$ to $2000 \mathrm{cc}-$ 5 (2000). 
ally applicable way. These restrictions on the application of RLUIPA are designed to confine the law's scope to specific delegations of power to Congress, and thus to avoid the excessive scope of regulation that led to invalidation of RFRA. RLUIPA also protects the free exercise rights of prisoners in state prisons that accept federal funds. State officials have bitterly resisted RLUIPA. The Supreme Court has unanimously rejected a claim that the prison provisions violate the Establishment Clause by giving preferred treatment to religion ${ }^{75}$ states are also arguing in the lower courts, mostly unsuccessfully, that both the prison and the land use provisions exceed the scope of powers delegated to Congress. RFRA, RLUIPA, and other legislative enactments to protect the free exercise of religion ${ }^{76}$ reveal the depth of disagreement on issues of regulating religious practice.

I have emphasized the ambiguity of Smith's requirement that laws regulating religion be "generally applicable," but in some applications, the meaning of that phrase is clear. A recent French example makes a helpful illustration. My point here is not to evaluate the French law, but to use this much-publicized French example to illustrate the relevant American concepts.

The new French law that prohibits students from wearing conspicuous religious items in public schools would not be a generally applicable law in the United States, even though it applies to all religions. It does not single out Muslims, or scarves or veils. But it singles out religious behavior and regulates that behavior because it is religious, without regulating equivalent secular behavior. If I understand the law correctly, a student can wear conspicuous secular jewelry but not conspicuous religious jewelry; a student can wear a scarf as a fashion statement but not as a religious statement. Despite intense disagreement on regulation of religious practice in the United States, this law is beyond the range of the American debate. I think that all informed American lawyers would say this law singles out religion and is not generally applicable.

Such a law might still be justified as serving a compelling government interest, but when a law openly discriminates against religion, the compelling interest test is hard to satisfy. A compelling interest in regulating only religion would normally mean the need to prevent some imminent and tangible harm. Creating

75. Cutter v. Wilkinson, 544 U.S. 709 (2005).

76. See American Indian Religious Freedom Act Amendments of 1994, 42 U.S.C. $\S 1996 a$ (2000); Religious Liberty and Charitable Donation Protection Act of 1998, Pub. L. No. 105-183 (codified as amended at 11 U.S.C. $\$ \S 544,546,548,707,1325$ ) (protecting churches and other charities from most claims of creditors of persons who contributed to the charity and subsequently went bankrupt). 
or preserving a more secular environment would not be a compelling interest; probably, in the American view of these issues, it is not even a legitimate interest. Accelerating the assimilation of Muslims might be compelling if assimilation is essential to addressing the problem of terrorism. But the usual response of American constitutional law to such problems is to punish individuals who violate the law, and not try to control large groups that contain some terrorists and many innocent people. And certainly courts would doubt whether the law will actually accelerate assimilation; it may just drive Muslim girls out of public schools. Protecting young Muslim women from coercion by their parents is an interest of doubtful legitimacy for minors; for adult women, it would require clear evidence that coercion is a widespread problem. I think the law would not serve compelling interests by American standards. But the compelling interest test is malleable and poorly defined; an American judge inclined to uphold such a law might persuade himself that one or more of these interests is compelling.

Finally, some American lawyers would argue that the law does not substantially burden religion, because it permits students to wear religious symbols that are inconspicuous. Some American judges seem to believe that government does not burden religion unless it interferes with a religious practice that is compulsory in the claimant's faith tradition. A Christian student wearing a large cross might be viewed as having made an individual choice, not mandated by her religion, so that limiting her to a small cross would not be a burden on her religion. ${ }^{77}$ This is a minority view in the United States; the Supreme Court's cases tend to the view that any religiously motivated behavior is an exercise of religion. ${ }^{78}$ But this disagreement would likely not matter with respect to yarmulkes or Muslim scarves; most students who wear one of these would say that their religion requires it, and that any interference with this religious obligation is a substantial burden on their exercise of religion.

The underlying American argument over regulating religious behavior involves multiple issues, and the two sides only partly correspond to the two sides in the cases on government funding and government-sponsored religious speech. Supporters of the Smith rule tend to think that neutrality is the fundamental principle in religious liberty cases, and by neutrality, they mean formal neutrality. Supporters of the Sherbert rule tend to think that liberty is the fundamental principle, or that neutrality should be understood as substantive neutral-

77. See Warner v. City of Boca Raton, 887 So. 2d 1023 (Fla. 2004).

78. Thomas v. Review Bd., 450 U.S. 707 (1981). 
ity, which brings neutrality more in line with liberty. From the perspective of the claimants in Smith and Lukumi, whose central religious rituals were subject to criminal penalties, it matters little whether the law was neutral and generally applicable. What matters is that it suppressed their religious liberty, and supporters of the Sherbert rule think that government should not do that without a very good reason.

Religious conservatives tend to support the Sherbert rule, because it better protects religious liberty. Secular conservatives tend to support the Smith rule, because it better preserves social order, it reduces the occasions for judges to invalidate laws on behalf of dissenters and minorities, and it saves judges from having to balance competing interests. Many secular liberals support the Sherbert rule, because it better protects individual liberty. But some support the Smith rule, because they see religion as a generally conservative cause in the United States, and because they think the Sherbert rule discriminates against nonbelievers. A religious conscientious objector to a law may get exempted under the Sherbert rule; a secular conscientious objector usually will not. During the Vietnam War, the Court interpreted the military conscientious objection statute to protect deeply held conscientious beliefs that lacked a conventional religious basis, ${ }^{79}$ and that approach goes far to solve the problem of discriminating against secular conscience. But it aggravates the fears of disorder, of excessive judicial intervention, and of difficult judicial decisionmaking. Current American judges are unlikely to protect secular conscience under statutes or constitutional provisions protecting the free exercise of religion. Realistically, the current struggle is over whether and to what extent they will protect the exercise of religion as religion has traditionally been understood.

\section{Conclusion}

Americans agree that government should not penalize any belief about religion, and that government should not pay for core religious functions. Beyond that, the United States has competing conceptions of religious liberty. Simplifying very greatly in order to summarize, one broad coalition would have government give nondiscriminatory financial support to religious schools and charities, give verbal support to mainstream religious faith, and regulate religiously motivated behavior only when absolutely necessary. An opposing coalition would

79. Welsh v. United States, 398 U.S. 333 (1970); United States v. Seeger, 380 U.S. 163 (1965). 
permit no government money for any religiously affiliated activity, would permit no government statements for or against religion, and would regulate religious behavior on substantially the same terms as nonreligious behavior. Each side is winning on some issues, losing on others. These coalitions are shifting and overlapping; important allies on one of these issues are often opponents on another. I examine all three sets of issues in greater depth in a recent article. ${ }^{80}$

I have emphasized the arguments in American law, and not just the rules. The arguments will persist; the rules are not so stable. Justices of the Supreme Court age, retire, and die; new justices will be appointed. The Court is deeply divided on all three sets of contested issues. The rules on funding religious institutions and regulating religious practice have changed in important ways in the last twenty years. The rules on religious speech have been more stable, but as I explained, those rules had the support of only two justices and now face an uncertain future.

American judges are not career employees in a specially trained branch of the civil service; federal judges are appointed by the president and confirmed by the Senate. In the short run, the American judiciary is insulated from politics. But in the long run, if an issue arouses intense and sustained public interest, the Supreme Court eventually responds to large changes in public opinion. So the arguments will continue, and the rules may change. But if you understand the arguments, you will be able to understand the changes in the rules.

80. Laycock, supra note 73. 
